\title{
Correspondence
}

\section{Postoperative pain management and acute pain service in Canada}

\section{To the Editor:}

Zimmermann and Stewart gave a very interesting survey of the development of acute pain services in Canada. ${ }^{1}$ We agree with most of their recommendations for pain therapy on normal wards and their reservations held against the use of epidural opioid analgesia (EOA) especially. Unfortunately, the authors quoted our German questionnaire survey ${ }^{2}$ wrongly, i.e., supporting the use of EOA on normal wards. On the contrary, this survey summarized more than 100 cases of severe respiratory depression in $25 \%$ of all departments questionned. This was the most frequent potential life-threatening side effect in this survey. Therefore, in accordance with most Canadian anaesthetists, we concluded that the use of EOA may not be recommended qutside of ICU or the recovery room unless very close monitoring of respiration and vigilance is guaranteed. The main argument is the delayed onset of respiratory depression (in contrast to immediate occurrence of hypotension following epidural local anaesthetics). Even the protagonists of EOA on normal wards ${ }^{3}$ recommend a respiratory monitor and ICU observations for the first $48 \mathrm{hr}$ for all patients with increased risk (e.g., age $>50 \mathrm{yr}$, ASA status $>$ II, thoracic or upper abdominal surgery). These criteria hold true for most of our patients where epidural analgesia was used. ${ }^{4}$ Under these circumstances the continuous infusion of low-dose bupivacaine seems to be a safer alternative, provided that visits to these patients (including neurological examinations) are made by an acute pain service at least once a day. 4,5

\author{
Christoph Maier MD \\ Hinnerk Wulf MD \\ Klinik für Anästhesiologie und Operative Intensivmedizin \\ University of Kiel \\ D24105 Kiel \\ Germany
}

\section{REFERENCES}

1 Zimmermann DL, Stewart J. Postoperative pain management and Acute Pain Service activity in Canada. Can J Anaesth 1993; 40: 568-75.
2 Maier C. Wawersik J, Wulf $H$. Ergebnisse einer Fragebogenerhebung zur Praxis und Organisation der postoperativen Periduralanalgesie an 461 Fachabteilungen fur Anästhesiologie. [Results of a questionnaire survey of the practise and organization of postoperative epidural analgesia in 461 departments of anesthesial]. Reg Anaesth 1991; 14: 61-9.

3 Ready LB, Oden R, Chadwick S. et al. Development of an anesthesiology-based postoperative pain management service. Anesthesiology 1988; 68: 100-6.

4 Maier C, Kibbel K, Mercker S, Wulf H. Postoperative Schmerztherapie auf Allgemeinen Krankenpflegestationen - Analyse der achtijährigen Tatigkeit eines Anăsthesiologischen Akut-Schmerzdienstes [Postoperative Pain Management on Surgical Wards - Eight Year's Experience of an Anesthesiology-based Acute Pain Service]. Anästhesist 1994 (in press).

5 Schug $S$, Torrie $J J$. Safety assessment of postoperative pain management by an acute pain service. Pain 1993; 55: 387-92.

\section{REPLY}

Thank you for the opportunity to respond to the concerns of Drs. Maier and Wulf. Their paper' was published in German and we based our comments on a Medline English abstract which stated "EA was administered in $62.4 \%$ on ordinary wards" and "... 66.7\% also favoured epidural opioids on ordinary wards." We interpreted these percentages to indicate the majority of those surveyed supported the use of epidural opiates on ordinary wards; however, if we have misrepresented their results we apologize.

We agree that respiratory depression is a major concern when administering epidural opioid analgesia. However, Ready does not recommend "... ICU observation for the first 48 hours for all patients with increased risk," but rather "... admission to ICU should be based on customary criteria such as medical status and the type and duration of surgery."2 In subsequent reports he confirms that adjustment of epidural morphine doses in combination with simple serial assessment of the level of consciousness allows for the safe administration of epidural opioids on regular hospital wards, even for those patients with advanced age and poor physical condition. ${ }^{3,4}$ This is the approach we have taken at our hospital and we have not had a single major adverse event that can be attributed to the use of epidural opioids on general surgical wards. We agree with Baxter ${ }^{5}$ that the risk of respiratory depression with postoperative opioids is the same regardless of the route they are administered.

Finally we disagree with the statement of Drs. Maier and Wulf that continuous epidural infusion of low-dose bupivacaine is a safer alternative than epidural opioids. Epidural local anaesthetics, even in low doses, have the potential to produce sympathetic, sensory, and motor blockade as well as cumulative 
toxicity related to the central nervous and cardiovascular symptoms. ${ }^{6}$ Clinical trials have documented side effects when lowdose bupivacaine is administered with epidural morphine. ${ }^{7}$ of the references cited by Drs. Maier and Wulf to support their statement, one is not yet published and the other reports the occurrence of high epidural blocks as well as one intrathecal migration of an epidural catheter. ${ }^{8}$ While no serious morbidity resulted from these events, you cannot use this as evidence that epidural local anaesthetics are safer than epidural opioids.

Despite the above concerns, we believe the combination of low-dose epidural bupivacaine and fentanyl or morphine does improve the efficacy of epidural analgesia and is safe on general postoperative wards provided the nursing staff are appropriately trained, monitoring protocols established, and physician assistance is available 24 hours a day. $I t$ is also our impression that since our survey was done, more centres in Canada are using epidural opioids alone or in combination with low-dose bupivacaine to improve the management of postoperative pain.

John C. Stewart MD FRCPC

Donald Zimmerman MD

Department of Anaesthesia

Foothills Hospital

Calgary.

\section{REFERENCES}

1 Maier C. Wawersik J, Wulf $H$. Ergebnisse einer Fragebogenerhebung zur Praxis und Organisation der postoperativen Periduralanalgesie an 461 Fachabteilungen fur Anästhesiologie. [Results of a questionnaire survey of the practice and organization of postoperative peridural analgesia 461 anesthesial departments]. Reg Anaesth 1991; 14: 61-9.

2 Ready LB, Oden R, Chadwick HS, et al. Development of an anesthesiology-based postoperative pain management service. Anesthesiology 1988; 68: 100-6.

3 Ready $L B, E d w a r d s W T$. Postoperative care following intrathecal or epidural opioids. II. Anesthesiology 1990; 72 : 213.

4 Ready LB, Loper KA, Nessly BS, Wild L. Postoperative epidural morphine is safe on surgical wards. Anesthesiology 1991; 75: 452-6.

5 Baxter $A D$. Editorial: Respiratory depression with patientcontrolled analgesia. Can J Anaesth 1994; 41: 87-90.

6 Grichnik K, Ginsberg B. Epidural analgesia for patients recovering from surgery. In: Sinatra RS, Hord AH, Ginsberg B, Preble LM (Eds.). Acute Pain: Mechanisms and Management. Chicago: Mosby Year Book, 1992.

7 Jayr C. Thomas H, Rey A, et al. Postoperative pulmonary complications; epidural analgesia using bupivacaine and opioids versus parenteral opioids. Anesthesiology 1993; 78: 666-76.

8 Schug SA, Torrie JJ. Safety assessment of postoperative pain management by an acute pain service. Pain 1993; 55: 387-91.

\section{Plasma cholinesterase activity in infants}

To the Editor:

We have read the Case Report by Pasquariello and Schwartz, ' describing plasma ChE deficiency in a twoday-old neonate. Indeed, this is the youngest reported patient to exhibit apnoea after succinylcholine. Laboratory testing confirmed plasma cholinesterase deficiency as the mechanism for prolonged neuromuscular relaxation. We would like to bring to the attention of readers that some neonates can have decreased plasma cholinesterase activity within the first two weeks of life. This activity usually reaches normal levels within one month of age. ${ }^{2}$ With respect to the infant described in the Case Report, analysis of plasma $\mathrm{ChE}$ activity should be made at an older age before a definitive diagnosis of cholinesterase deficiency is made. This is especially important since both parents and an older sibling had normal cholinesterase activity. Genetic analysis of the neonate's DNA would confirm the presence of a silent gene.

Susan A. Vassallo MD

Nishan G. Goudsouzian MD

Harvard Medical School

\section{REFERENCES}

1 Pasquariello CA, Schwartz RE. Plasma cholinesterase deficiency in a neonate. Can J Anaesth 1993; 40: 529-31.

2 Strauss AA, Modanlon HD. Transient plasma cholinesterase deficiency in preterm infants. Dev Pharmacol Ther 1986; 9: 82-7.

\section{$R E P L Y$}

We thank Drs. Vassallo and Goudsouzian for their comments. We have been attempting to contact the family for a followup plasma cholinesterase level (PChE). Strauss ${ }^{l}$ reported a group of premature infants, $16 \%$ of whom had abnormally low PChE. The lowest value he reported in that group was $4 \mathrm{U} \cdot \mathrm{ml}^{-1}$ (normal $>7 \mathrm{U} \cdot \mathrm{ml}^{-1}$ ) or approximately $57 \%$ of normal. This included the values of a pair of twins with persistently low PChE, thought to be a genetic abnormality. Zsigmond and Downs ${ }^{2}$ found the mean PChE activity of infants and newborns to be approximately $50 \%$ of adults. These results double and approach adult values, by several weeks of age. Because the PChE level of our patient ${ }^{3}$ was $0.2 \mathrm{U} \cdot \mathrm{ml}^{-1}$ (5.8\% of normal), we felt that this showed practically no $P C h E$ activity and an increase of 10-20-fold to reach "normal" values would be highly unlikely given the above data. If we are able to obtain a follow-up plasma cholinesterase level on our patient, we will report our findings.

Caroline A. Pasquariello MD

Roy E. Schwartz MD 